\title{
Education, ethics, and solidarity in international cooperation
}

Janete Lima de Castro

Professor, Departamento de Saúde Coletiva/ Universidade Federal do Rio Grande do Norte (UFRN). Campus Universitário, BR 101, Lagoa Nova 59072-970 - Natal - RN - Brasil janetecastro.ufrn@gmail.com

\section{Rosana Lucia Alves de Vilar}

Professor, Departamento de Enfermagem/ Centro de Ciências da Saúde/UFRN. Campus Universitário, BR 101, Lagoa Nova 59072-970 - Natal - RN - Brasil

rosanaalvesrn@gmail.com

\section{Raimunda Medeiros Germano \\ Professor, Departamento de Enfermagem/ Centro de Ciências da Saúde/UFRN. \\ Campus Universitário, BR 101, Lagoa Nova 59072-970 - Natal - RN - Brasil \\ rgermano@natal.digi.com.br}

Received for publication in August 2013.

Approved for publication in October 2014.

Translated by Diane Grosklaus Whitty.
CASTRO, Janete Lima de; VILAR, Rosana Lucia Alves de; GERMANO, Raimunda Medeiros. Education, ethics, and solidarity in international cooperation. História, Ciências, Saúde - Manguinhos, Rio de Janeiro, v.22, n.1, jan.-mar. 2015. Available at: http://www.scielo.br/hcsm.

\section{Abstract}

The article analyzes an experience in technical cooperation between Brazil and Andean countries in the form of the International Course in the Management of Human Resource Policies in Health. This exploratory documental study encompassed a number of Latin American countries whose institutions of higher education had partnerships with the Federal University of Rio Grande do Norte, mediated by the Pan American Health Organization Representation in Brazil. The course experience shows that fundamental values like ethics and solidarity are determinant to the success of technical cooperation processes.

Keywords: technical cooperation; human resources for health; education. 
$\mathrm{A}$ ccording to the United Nations Program for Development (UNDP), South-South Cooperation (SSC) is a collective development mechanism that emerging nations can rely on to respond to common challenges. In the view of Santana (2011), many health services worldwide encounter common difficulties that are associated with low-quality, low-efficacy health actions. In the words of this author, "the combination of common challenges and shared interests in tackling these challenges offers opportunities for cooperation between countries" (p.2994). ${ }^{1}$ According to Verenhitach, Deitos, and Seitenfus (2007, p.2), "in addition to promoting the development of countries of the South, triangular South-South cooperation is meant to empower these countries through an exchange of knowledge and experiences needed for them to attain a critical view of their own development." In the opinion of these authors, Brazil has much to offer less advanced countries, and triangular South-South cooperation affords a promising way to achieve this. Further according to the authors, triangular cooperation can also entail partnerships between two countries and an international organization, institution, or agency, like the Brazilian Cooperation Agency (Agência Brasileira de Cooperação, or ABC).

It is from this perspective that the present article analyzes the experience of the International Course in the Management of Human Resource Policies in Health (Curso Internacional em Gestão de Políticas de Recursos Humanos em Saúde), known by the acronym CIRHUS; as a technical cooperation project conducted through an educational process, CIRHUS proposed to share common experiences, problems, and solutions in the management of human resources for health (HRH) across different countries.

How can one share an experience while recognizing the experience of the other? How can one engage in cooperation initiatives while respecting the autonomy of the agent who is the recipient of the initiative? These are some of the questions addressed in this paper.

According to Puente (2010, p.32), Brazil has taken part in the evolution of international technical cooperation since its earliest days. Although the country was a recipient in the beginning and for many years, it later began sharing its experience and knowledge in a gamut of fields. In the opinion of the cited author, "Brazil's horizontal technical cooperation initiatives have encompassed activities, projects, and programs that involve the transfer, production, and dissemination of technical knowledge, successful experiences, and human resource (HR) training aimed at strengthening institutions in the recipient country." Within this context, the present paper addresses CIRHUS as a strategy that has the potential to foment cooperation processes in the realm of health services.

The CIRHUS project came into being in the latter half of the 1980s, when Brazil was engaged in a number of experiences focused on the urgent need to address issues in HRH, more recently designated in Brazil "Management of Work and Education in Health" (Gestão do Trabalho e da Educação na Saúde). Castro (2008) cites some of these initiatives, particularly two: the Project for Training in the Development of Human Resources in Health (Projeto Capacitação em Desenvolvimento de Recursos Humanos em Saúde, or CADRHU), whose goal was large-scale training of HR managers at Brazilian health departments, and the Latin American Course in Human Resources for Health (Curso Latino-americano de Recursos Humanos em Saúde, or CLARHUS). 
Sponsored by the Brazilian Ministry of Health and the Pan American Health Organization (PAHO) and conducted by Brazilian universities, CADRHU accomplished a number of goals: it provided HR training for some three thousand professionals from 1987 to 1999; it helped strengthen ties between universities and health departments and between the latter and institutions from other sectors; it fostered the creation of technical and scientific documents on the issue of resources; and it brought the topic of HR training into the public eye, thus playing a role in earning it a priority position on the agenda for health managers.

Held in 1992 at the Oswaldo Cruz Foundation's Sergio Arouca National School of Public Health (Escola Nacional de Saúde Pública Sergio Arouca) under the sponsorship of PAHO, the CLARHUS project trained a number of HR specialists who went on to hold posts at various health ministries in Latin America. According to Ferreira and Campos (2010), when graduates of CLARHUS returned to their home countries, they played an important role both academically and administratively in promoting better management in the field of HRH. In an interview to Castro (2008), Francisco Campos said that CLARHUS expanded on the CADRHU experience, turning it into a continent-wide project.

The 1990s and 2000s witnessed substantial growth in the health workforce, in the network of training institutions, and in the list of problems identified as HR issues. These issues include insufficient personnel, workforce outsourcing, professional demotivation, the lack of skilled management, challenges in placing workers in more remote or harder-to-reach areas, early specialization, and the gap between training and the day-to-day reality of health services. If, on the one hand, there has been an awareness of some of these issues since the time of the initial studies that led to the mid-1970s creation of the Program for the Strategic Preparation of Health Personnel (Programa de Preparação Estratégica de Pessoal em Saúde, or PPREPS) by PAHO (Opas, 1973), on the other hand, new problems began to arise later and became chronic over time.

This scenario once again prompted Brazilian institutions to join forces around an international cooperation project, this one intended to provide HRH training in Latin American countries. The experience acquired through both CADRHU and CLARHUS formed the basis for the CIRHUS project, which included nine countries and many institutions (health ministries, PAHO, and universities). Following in the footsteps of the earlier two initiatives, CIRHUS elected education as the driving force behind the technical cooperation initiative.

According to Castro (2010), two of the goals set by CIRHUS were to strengthen managers' ability to direct HRH policies and to build international consortiums in technical cooperation, or collaborative networks, in the field. The present article focuses on this experience through an examination of Brazilian activities in technical cooperation. It analyzes the Brazilian government's experiences in rendering technical cooperation assistance in HRH to Andean countries from 2006 to 2010 through CIRHUS and reflects on the relevance of ethics, solidarity, and responsibility as values fundamental to the cooperation process.

Relying on the application of techniques for comprehending, understanding, and studying different types of documents, the present study placed priority on a qualitative approach using documental research as a source of information (Sá-Silva, Almeida, Guindani, 2009). Analyzed documents included course evaluations by students, technical consultancy reports for PAHO, workshop reports, and other governmental and institutional documents on the topic. 


\section{CIRHUS: its development, results, and impacts}

The origin of CIRHUS lies in the signing of Technical Cooperation Agreement no.41 (TC-41) between PAHO/WHO and Brazil. The agreement set in motion "a modality of cooperation between countries incentivized by resources that Brazil contributed to $\mathrm{PAHO} /$ WHO, the agency that assumes the commitment of exchanging and potentializing these processes" (Santana, 2010, p.7). In addition to TC-41, this triangular cooperation was grounded on the Technical Cooperation Strategy for PAHO/WHO and the Federative Republic of Brazil, 2008-2012 (Estratégia de Cooperação Técnica da OPAS/OMS com a República Federativa do Brasil 2008-2012), still according to Santana (2011). This author also reports that Brazil's earlier successful cooperation experiences in a national context influenced the decision to adopt a triangular cooperation model encompassing Brazil, other countries, and PAHO/WHO. In their analyses of some of these experiences, Pires-Alves and Paiva (2006) and Castro (2008) highlight the role of the PAHO/WHO Representation in Brazil.

Authors like Velasco et al. (2011) and PAHO (Opas, 2010) emphasize that CIRHUS is an educational process conjoined to a proposal for institutional development involving the ministries of health, universities, and PAHO representations of each participating membercountry in the Andean region.

But did CIRHUS successfully share the Brazilian experience and build something new based on the principles of dialogue, ethics, and respect for each nation's reality? In other words, when CIRHUS conducted its work, did it take into account the fact that cooperation processes demand reciprocity? Moreover, did CIRHUS take into account that subjects are autonomous and see themselves as interlocutors in a given process, as suggested by Boff (2000)?

During these experiences, the CIRHUS was organized in four learning units: Introduction; Health Services and Human Resources: Issues and Determinants; Education for Health Work; and HRH Management. The units were divided into modules that engendered ongoing interaction between theory and practice and were meant to contribute to a re-organization of the management process. Specific content was part of an integrated whole that spoke to the work being done by the students, thereby encouraging the integration of teaching and work.

According to Castro (2010), this cooperation initiative adopted the educational process as its strategy and critical pedagogy as its approach, based on problem-posing methodology. Pereira (2003) states that the proposal of critical pedagogy is to prompt change in tune with the following principles: education as a social and political act; the student as a historical and social being; education for concrete reality; content that is alive and open; and education always for transformation.

In reporting on the CIRHUS experience in the Andean region, Acosta (2011) states that the adopted reflexive, critical methodology substantially enhanced the learning experience by addressing HR problems in association with other health service issues.

In this regard, we can affirm that the theoretical reference for CIRHUS pedagogy was problem-posing methodology, whereby the acquisition of knowledge is linked to social context and where the student's rather inchoate experiences in practice are juxtaposed with the content proposed by the course in order to develop a new consciousness of this practice. 
In their evaluations of the CIRHUS, students related some of the results: "The course really helped us look farther, that is, it helped us arrive at a clear, objective view of what human resource management is about" (CIRHUS student) (Castro, 2010, p.26).

Cyrino et al. (2004) emphasize that problem-posing education approaches the construction of knowledge on the basis of actual experience and is underpinned by discovery-based learning rather than learning through received ideas. Content is not presented in finished form but in the form of problems whose solutions must be discovered and forged by the students, who reorganize knowledge and not only adapt it to their previous cognitive structure but also discover new relations and forms of intervention.

Berbel (1998) points out that the general guideline in problem-posing methodology is to pass through a series of interconnected stages based on an actual, identified problem as a way of preparing the student to grasp this reality and intervene in it.

The following statement evinces the impact of the methodology used by CIRHUS and what the students took away, as corroborated in the analyses of Berbel (1998): "In the 10 years that I've worked at the Ministry of Public Health, this is the first time I've received such top-quality training, which will stimulate me to work with commitment and responsibility at my institution" (CIRHUS student) (Castro, 2010, p.25).

Berbel (1998) also recognizes problem posing as a valuable learning method for the health area; in addition to stimulating mental processes, it develops in the student critical, creative attitudes toward his or her context and prepares him or her purposefully and systematically to intervene in this context.

In this regard, it is worth examining how CIRHUS students replied when asked about the relevance of the course to their professional practice and their institution (Castro, 2010). According to the students, the course prepared them to take on new challenges and face institutional changes; it also allowed them to reflect on institutional practices and compare these with the situations in other countries; it allowed them to reflect on and achieve change; it prepared them to better perform their duties and to exchange experiences among local bodies and between local and central bodies; and it helped them understand and analyze various aspects of the HR field and apply this at their institutions.

Velasco (2010, p.50) cites some results of CIRHUS/Ecuador in her article on the experience there. She states that the results of the cooperation process between Brazil and Ecuador, mediated by CIRHUS, can be summed up as follows:

- Firm establishment of a new team of instructors specialized in HRH at the Public Health Institute of the Central University of Ecuador, who are now skilled in problem-posing methodologies and in implementing a syllabus for a specialization course in HRH.

- Adaptation of the course to Ecuador, which gave the Institute of Public Health a new opportunity beyond the envisioned results, that is, to draft viable intervention projects at each place where the student carries out his or her duties.

- Production of intervention projects for development at workplaces, with prior discussions among the students responsible for these projects, their work colleagues, and their chiefs.

Other studies, such as Acosta's (2011), cite some impacts of the CIRHUS project in Ecuador, Peru, Chile, and Colombia. According to Acosta: 
- The project left its mark on the management of the country's Ministry of Health, leaving a demarcation between "before CIRHUS" and "after CIRHUS." Staff at both the provincial and central levels (Ministry of Health) were involved in planning for project continuity in Ecuador, marking a shift in the relations between the national and decentralized levels.

- The Public Health Institute at the Central University of Ecuador continued to offer the course in partnership with the PAHO Representation in Ecuador and its Ministry of Health. This initiative deserves special mention since CIRHUS was the first course for HRH managers conducted by the Institute, in partnership with the country's Ministry of Health.

- In Colombia, CIRHUS graduates introduced new elements into the discussion of HRH policies and regulations and emphasized their importance in health system management.

- In Peru, CIRHUS contributed to the establishment of other proposals for health worker training, such as family-focused comprehensive health care; it also helped to enrich the national Pro-Health proposal and to inform discussions on health careers and HR allocation policies in areas of poverty. It has been reported that health services and teaching institutions have improved their integration for the purpose of training HR managers.

- Participants from universities in Peru, Ecuador, and Chile agree that the design of CIRHUS affords an opportunity to improve skills in HRH policy management. According to these participants, the course set the stage for an exchange of knowledge, dialogue, and the harmonization of ideas; students developed the ability to see other perspectives in HR policy management; it prompted students to rank research as an important activity for HR managers; through practical exercises, it compelled students to reflect on the reality of their organizations and therefore gain a broader view of their operations; and, lastly, it allowed students to develop proposals to be carried out at their own workplaces.

The results presented here evoke Paulo Freire (2006, p.47) when he says "teaching is not about transferring knowledge but about creating the possibility that [knowledge] will be produced or constructed." From this perspective, we believe that the CIRHUS project in the Andean region guaranteed its success because the content of the Brazilian course was gradually adapted to each country's circumstances, based on the supposition that the student participants would be capable of reflecting on their own learning experience (Masseto, 2009) and of changing undesired realities.

During this process of adaptation, the teams of Andean instructors were advised by instructors from the Federal University of Rio Grande do Norte (Universidade Federal do Rio Grande do Norte, or UFRN), who were experienced in CADRHU methodology. UFRN's participation was mediated by the PAHO/WHO Representation in Brazil, thus configuring a triangular model of technical cooperation between Brazil and other countries, mediated by $\mathrm{PAHO} / \mathrm{WHO}$, as mentioned earlier.

In this regard, Acosta (2011, p.14) states:

The transfer of methodology represented a fundamental process on the road to institutionalization. To this end, political and technical mechanisms were employed that allowed a team of specialists to tailor the design of the Brazilian course. In this regard, PAHO's participation as an intermediary between the Federal University of 
Rio Grande do Norte and the health ministries and universities of the participating countries proved extremely valuable.

The project fostered experiences that substantiated other teachings of Freire, Freire, and Oliveira (2009) on the pedagogy of solidarity and the ethical nature of educational practice. The question of solidarity was comprehended in this process not only as a political matter but also as a methodological one. During the educational process, solidarity has a direct bearing on how the discussions are led and encouraged, as well as on their results in the real world.

In the opinion of Freire, Freire and Oliveira (2009), solidarity walks hand in hand with critical consciousness. The author stresses that education has a responsibility when it comes to bettering the world, and this means understanding and coping with existing problems, fashioning and implementing intervention strategies to overcome these problems, and having the flexibility to change strategies whenever necessary. All this presumes that feelings and behaviors of solidarity are adopted.

Germano (2007, p.49) points out that in its broadest sense, solidarity presupposes "including the other, taking responsibility toward others, and expanding the meaning of 'us'. Therefore, there is no solidarity without otherness, that is, without a bond with the other. This implies shared interests and bonds of identity and belonging."

The technical cooperation initiative conducted through CIRHUS prompted an exchange of experiences and a transfer of technology while respecting the specificities of each context. By protecting freedom of choice and the desire for equal conditions, the fraternal approach that was adopted enforced an ethics of solidarity in the relations established between the representatives of Brazil and of other countries. We can therefore affirm that in its method and proposals, the course enforced a pedagogy of solidarity in the realm of horizontal cooperation.

Freire (2006) argues that educational practice, as a teaching practice and as a specifically human practice, demands great ethical responsibility, and these ethics must be consonant with the presuppositions of universal human ethics, understood as ethics that override market interests and recognize human rights and citizenship.

Further according to Freire, universal human ethics are inseparable from educational practice, and the best way to fight for these ethics is for teachers to live them and witness to them in their relations with students, in the way that they approach the content they teach and the methods they use.

The pedagogical concept applied in the CIRHUS allowed students to share their real-life experiences and for this very reason required that the teacher display attitudes of respect and ongoing learning as he or she encountered the expression of different stances and understandings. Furthermore, as active participants in educational practice, as historical subjects of quests, decisions, turning points, and choices, and as transformers of reality, the educatees also had to recognize themselves as ethical subjects. After all, "scientific training, ethical correctness, respect for the other, coherence, the ability to live and learn with what is different... are commitments to which we must persistently devote ourselves" (Freire, 2006, p.16).

In other words, we can say that the relations established during this process of horizontal, democratic, and participative cooperation were pervaded by the ethics of co-responsibility 
and solidarity - co-responsibility in the sense that support was provided to the participating subjects through educational actions of a political, transformative character that respected the diversities of each country, and solidarity in the sense of sharing experiences with the purpose of exchanging knowledge and practices in order to strengthen the ability to deal with the various challenges of HRH policies.

\section{Final considerations}

The present paper examined an experience in international technical cooperation in HRH between Brazil and countries in the Andean region through the International Course in the Management of Human Resource Policies in Health. Special focus was placed on the ethical and solidarity aspects of an educational process whose purpose was to mediate a cooperation activity between countries, starting from an experience that had been tested and proven in Brazil but without overlooking the fact that local realities display unique features that merit respect.

One of Freire's teachings was the premise behind this proposal for Brazilian cooperation in the form of a training process, that is, that teaching demands respect for the autonomy of the educatee. As educators and cooperative beings, we must constantly remind ourselves of this cautionary demand: "Respect for the autonomy and dignity of every person is an ethical imperative and not a favor that we may or may not concede to each other" (Freire, 2006, p.59).

This cooperation perspective stands apart from a number of other experiences over the history of international cooperation in health, yet it was recognized and accepted by participating institutions, which lent their political, technical, and financial support to its development.

The joint efforts of institutions like ministries of health, PAHO, and the universities in participating countries represent one chapter in the history of this cooperation. It deserves to be studied in greater depth, with an emphasis on the fact that where there is political will, technical knowledge, and respect among participants, desires become reality.

It is also important to emphasize that in light of the complex diversities of current health realities, the feeling of solidarity among human beings is one of the roads to forming a moral community of citizens of the world. And cooperation seems to be the keyword in this process of social transformation.

In conclusion, it is important to understand that CIRHUS is an unfinished process - yet isn't unfinishedness essential to our human condition, as Paulo Freire said? Lastly, by regarding CIRHUS as unfinished, it is our intention to accentuate the need for its leaders to constantly revise it, evaluating its development in different countries and drawing up recommendations that bring its content in line with ever-changing social, economic, political, and institutional contexts.

\section{NOTE}

${ }^{1}$ In this and other citations of texts from non-English languages, a free translation has been provided. 


\section{REFERENCES}

ACOSTA, Zully.

Balance y perspectiva CIRHUS Subregión andina 2008-2010. Cooperación com equidade, excelencia, solidaridad, respeto e integridade. (Documento Síntesis del Balance del Proceso de implementación del Proyecto CIRHUS en la Subregión andina 2008-2010 y los acuerdos de la Reunión - Natal 2011). Disponível em: http://www.observatoriorh.org/sites/default/ files/webfiles/fulltext/balance\&perspectivas cirhus_2007_2010.pdf. Acesso em: 22 abr. 2012. 2011.

BERBEL, Maria Aparecida N.

A problematização e a aprendizagem baseada em problemas: diferentes termos ou diferentes caminhos? Interface-Comunicação, Saúde e Educação, n.2, p.139-154. 1998.

BOFF, Leonardo.

Ethos Mundial: um consenso mínimo entre os humanos. Brasília: Letraviva. 2000.

CASTRO, Janete Lima de.

Cirhus: fortalecimento solidário do campo de recursos humanos em saúde. In: Organização Pan-Americana da Saúde. Cooperação técnica entre países para a formação de dirigentes de recursos humanos em saúde. Brasília: Organização Pan-Americana da Saúde. p.11-31. 2010.

CASTRO, Janete Lima de.

Protagonismo silencioso: a presença da Opas na formação de recursos humanos em saúde no Brasil. Natal-RN: Observatório RH-Nesc/UFRN; Ministério da Saúde; Opas/OMS. 2008.

CYRINO, Eliana G. et al.

Trabalhando com estratégias de ensinoaprendizado por descoberta na área de saúde: a problematização e a aprendizagem baseada em problemas. Cadernos de Saúde Pública, v.20, n.3, p.780-788. 2004.

FERREIRA, José Roberto; CAMPOS, Francisco.

O Cirhus em perspectiva histórica. In:

Organização Pan-Americana da Saúde.

Cooperação técnica entre países para a formação de dirigentes de recursos humanos em saúde. Brasília: Organização Pan-Americana da Saúde. p.33-36. 2010.

FREIRE, Paulo.

Pedagogia da autonomia: saberes necessários à prática educativa. São Paulo: Paz e Terra. 2006.

FREIRE, Paulo; FREIRE, Nita; OLIVEIRA, Walter Ferreira.

Pedagogia da solidariedade. Indaiatuba: Villa das Letras. 2009.
GERMANO, José Willington.

Globalização contra-hegemônica, solidariedade e emancipação social. Cronos, v.8, n.1, p.45-55. 2007.

MASSETO, Marcos T.

Formação pedagógica dos docentes do ensino superior. Revista Brasileira de Docência, Ensino e Pesquisa em Administração, v.1, n.2, p.4-25. 2009.

OPAS.

Organização Pan-americana da Saúde. Cooperação técnica entre países para a formação de dirigentes de recursos em saúde. Brasília: Opas. 2010.

OPAS.

Organização Pan-americana da Saúde. Acordo para um Programa Geral de Desenvolvimento de Recursos Humanos para a Saúde no Brasil. Brasília: Opas. 1973.

PEREIRA, Adriana L. de Figueredo. As tendências pedagógicas e a prática educativa nas ciências da saúde. Cadernos de Saúde Pública, v.19, n.5, p.1527-1534. 2003.

PIRES-ALVES, Fernando A.; PAIVA, Carlos Henrique Assunção.

Recursos Críticos: história da Cooperação Técnica Opas-Brasil em Recursos Humanos para a Saúde (1975-1988). Rio de Janeiro: Fiocruz. 2006.

PUENTE, Carlos Alfonso Iglesias.

A Cooperação Técnica Horizontal Brasileira da Política Externa: a evolução da cooperação técnica em países e desenvolvimento - CTPD - nos períodos 1995-2005. Brasília: Funag. 2010.

SANTANA, José Paranaguá de.

Um olhar sobre a cooperação sul-sul em saúde. Ciência \& Saúde Coletiva, v.16, n.6, p.2993-3002. 2011.

SANTANA, José Paranaguá de.

A Cooperaçao Sul-Sul na formação de dirigentes de recursos humanos em saúde. In: Organização Pan-Americana da Saúde. Cooperação técnica entre países para a formação de dirigentes de recursos humanos em saúde. Brasília: Organização Pan-Americana da Saúde. p.7-9. 2010.

SÁ-SILVA, Jackson Ronie; ALMEIDA, Cristóvão Domingues de; GUINDANI, Joel Felipe.

Pesquisa documental: pistas teóricas e metodológicas. Revista Brasileira de História e Ciências Sociais, ano 1, n.1, p.1-15. 2009.

VELASCO, Margarita A.

Cirhus: a experiência equatoriana. In: Organização Pan-Americana da Saúde. Cooperação técnica entre países para a formação de 
dirigentes de recursos humanos em saúde. Brasília: Organização Pan-Americana da Saúde. p.46-53. 2010.

VELASCO, Margarita A. et al.

Curso de Especialización en Gestión de Políticas de Recursos Humanos en Salud (Cirhus Ecuador): reflexiones pedagógicas y prácticas transformadoras. Quito: Universidad Central del Ecuador; Organización Panamericana de la Salud. 2011.
VERENHITACH, Gabriela; DEITOS, Marc; SEITENFUS, Ricardo.

O Brasil e a cooperação triangular sul-sul para o desenvolvimento: o caso do Haiti. Trabalho apresentado no Simpósio em Relações Internacionais do Programa de Pós-Graduação em Relações Internacionais San Tiago Dantas (Unesp, Unicamp e PUC-SP, 12-14 nov. 2007). p.1-16. Disponível em: http://www. santiagodantassp.locaweb.com.br/br/simp/ artigos/verenhitach.pdf. Acesso em: 23 set. 2014. 2007.

\section{$\rightarrow \rightarrow \rightarrow<<<$}

